\title{
Plasmacytoid dendritic cells and immunotherapy in multiple sclerosis
}

\author{
Felipe von Glehn ${ }^{1}$, Leonilda M Santos ${ }^{1}$, and Konstantin E Balashov ${ }^{\star}{ }^{2}$ \\ ${ }^{1}$ Neuroimmunology Unit, Department of Genetics, Evolution \& Bioagents, University of Campinas, \\ Rua Monteiro, Lobato, 255, Campinas, SP Brazil, CEP 13083-970, Brazil \\ 2Department of Neurology, Robert, Wood Johnson Medical School, 125 Paterson Street, Rm \\ 6213, New Brunswick, NJ 08901, USA
}

\section{Abstract}

Plasmacytoid dendritic cells (pDCs) are specialized APCs implicated in the pathogenesis of many human diseases. Compared with other peripheral blood mononuclear cells, pDCs express a high level of TLR9, which recognizes viral DNA at the initial phase of viral infection. Upon stimulation, these cells produce large amounts of type I interferon and other proinflammatory cytokines and are able to prime $\mathrm{T}$ lymphocytes. Thus, $\mathrm{pDCs}$ regulate innate and adaptive immune responses. This article reviews select aspects of pDC biology relevant to the disease pathogenesis and immunotherapy in multiple sclerosis. Many unresolved questions remain in this area, promising important future discoveries in $\mathrm{pDC}$ research.

\section{Keywords}

innate immunity; multiple sclerosis; plasmacytoid dendritic cells; Toll-like receptors; type I interferon

\footnotetext{
Since the early reference to plasmacytoid dendritic cells (pDCs) in the paracortical area of reactive lymph nodes in 1958 by Lennert and Remmele [1], an abundance of new information about their important role in the immune system has emerged. The most important milestones in their characterization are:

- Initial determination of their surface phenotype $\left(\mathrm{CD} 4^{+}, \mathrm{CD} 123^{+}[\mathrm{a}\right.$-chain of IL-3 receptor] and $\mathrm{CD}^{+} 8^{+}$[ [2,3];

- Isolation of pDCs from human blood in 1999 [4,5];

- Identification of BDCA-2 (CD303) and BDCA-4 (neuropilin-1) on pDCs as selective $\mathrm{pDC}$ markers [6,7];

- Discovery of the murine counterpart in 2001 [8-10];

- In vitro establishment of derivation of pDCs from human and murine hematopoietic progenitors $[11,12]$.
}

\footnotetext{
(C) 2012 Future Medicine Ltd

*Author for correspondence: Tel.: +1 732235 7727, Fax: +1 732906 5705, kbalashov@yahoo.com.

Financial \& competing interests disclosure

The authors have no other relevant affiliations or financial involvement with any organization or entity with a financial interest in or financial conflict with the subject matter or materials discussed in the manuscript apart from those disclosed.

No writing assistance was utilized in the production of this manuscript.
} 
pDCs are the major producers of type I interferons and have the unique ability to link innate and adaptive immunity. After microbial stimulation, they can also differentiate into mature pDCs capable of stimulating naive T cells and modulate the adaptive immune response [13].

\section{Characterization of $\mathrm{pDCs}$}

pDCs are known to be a small population of bone marrow-derived cells $(0.3-0.5 \%$ of the human peripheral blood) that traffic directly from blood via high endothelial venules to organized lymphoid structures in the steady state, mainly to T-cell areas of lymph nodes and spleen, mucosal-associated lymphoid tissues, thymus and liver $[3,14,15]$. They originate in the bone marrow from a common dendritic cell (DC) progenitor, a distinct progenitor type that expresses cytokine receptors Flt3, M-CSFR (CD115) and low levels of c-Kit (CD117) $[16,17]$. The cytokine Flt3 ligand appears to provide the central signal for pDC development, through its receptor and transcription factor STAT3, controlling the expansion of common progenitors and peripheral DC homeostasis [18]. The pDC lineage commitment is linked to expression of the basic helix-loop-helix transcription factor E2-2 (E protein), which controls the synthesis of other $\mathrm{pDC}$-specific transcription factors involved in cell development and function, for example, BDCA-2, ILT-7 and IRF7 [19]. The low expression of the DNA-binding protein inhibitor ID-2, in contrast to abundant ID-2 expression in T, NK and myeloid cells, increases the effective E2-2 concentration in pDCs [19].

Immature pDCs express low levels of MHC class II and costimulatory molecules. pDCs are negative for the integrin CD11c but positive for the B-cell marker B220/CD45RA [20]. Furthermore, they have been found to contain recombination-activating gene products and show D-J rearrangements of the immunoglobulin heavy chains [21]. Notably, these features of steady-state pDCs are similar to those of lymphocytes but are distinct from those of conventional DCs (cDCs).

pDCs can be distinguished from other blood cells based on the selective expression of BDCA-2 [6,7] and ILT-7 [22,23]. Human pDCs also express CD4, MHC class II, IL3R, BDCA-4 (neuropilin-1) and CD2 [24]. Human pDCs lack the lineage markers CD3, CD19, CD14, CD16 and cDC marker CD11c [24].

Although most nucleated cells produce type I IFN- $\alpha / \beta$ ) upon infection with viruses, pDCs have the unique feature of producing more type I interferons than any other cell type in response to viruses and/or virus-derived nucleic acids [25]. TLR7 and 9 are highly expressed in pDCs and B cells. Upon activation with viral nucleic acids, they induce stimulation and recruitment of the adaptor protein MyD88 and two major TLR7/9 intracellular signaling pathways. The first pathway leads to type I interferon production, which requires the translocation of IRF7 to the nucleus promoting IFN- $\alpha / \beta$ transcription $[26,27]$ and the second pathway leads to expression of TNF- $\alpha$ and IL-6, mediated by NF- $\kappa \beta$ signaling [28]. TLR7 and 9 are exclusively expressed in intracellular endosomal compartments [29]. TLR7 recognizes viral ssRNA [30,31] and TLR9 detects viral dsDNA rich in unmethylated CpG oligonucleotides $[32,33]$. This leads to induction of type I interferon secretion in an IFN- $\alpha / \beta$ receptor-independent manner [34], although this IFN- $\alpha / \beta$ receptor-mediated positive feedback is still active in pDCs [35].

To avoid the possibility of uncontrolled interferon secretion, multiple pDC-specific molecules inhibit human pDC function. BDCA-2 and ILT-7 attenuate Toll-like receptor (TLR)-induced production of interferons and other cytokines [36]. They signal through a common pathway that involves the $\gamma$ - and $a$-chain of the high-affinity $\mathrm{Fc}$ receptor for IgE (FceRI $\gamma$ and FceRIa) [22] and NKp44, which signals through DAP12 [37]. 
Furthermore, when activated, pDCs produce IL-6, TNF- $a$ and chemokines, for example, CXCL9 (MIG), CXCL10 (IP-10), CCL3 (MIP-1a), CCL4 (MIP-1 $\beta$ ) and CCL5 (RANTES) [38], which are able to attract activated CD4 and CD8 T cells to the sites of inflammation and upregulate the chemokine receptor CCR7, directing them through its ligand CCL21 and CCL19 to secondary lymph organs to prime naive T cells [39]. Recent data obtained in situ showed that pDCs accumulate in lesions of type I interferon-related disorders (e.g., lupus erythematosus and psoriasis), Th2 cell-dominated allergic reactions and ovarian carcinoma [40]. This migratory pathway to peripheral nonlymphoid tissues is poorly understood. Human pDCs express ChemR23, which directs pDC migration through its agonist chemerin [41]. Chemerin is constitutively produced by endothelial cells and fibroblasts as an inactive chemokine precursor and activated by serine proteases produced in damaged tissues [41]. Additional chemoattractants for pDCs in damaged tissues are adenosine [42] and anaphylatoxins C3a and C5a [43]. pDCs also express CXCR3, a receptor for the inflammatory chemokines CXCL10 (IP-10), CXCL11 (ITAC) and CXCL9 (MIG), as well as CXCR4, a receptor for CXCL12 (SDF-1). CXCR4-SDF-1 interactions are an important mechanism of extravasation of pDCs to lymphoid tissues [38]. Therefore, pDCs may influence both innate and adaptive immune responses.

Type I interferons, secreted by pDCs activated with foreign nucleic acids, promotes longterm T-cell survival and memory [44,45], Th1 polarization [46], CD8 T-cell cytolytic activity, NK cell-mediated cytotoxicity and IFN- $\gamma$ production $[47,48]$. On the other hand, in the presence of only IL-3 and CD40 ligand, pDCs undergo a different maturation process [3] and, in vitro, induce naive $\mathrm{T}$ cells to produce $\mathrm{Th} 2$ cytokines [49].

IL-6 and type I interferons can induce the differentiation of B cells into immunoglobulinproducing plasma cells [50,51]. However, it seems that a physical interaction between pDC CD70, a TNF family ligand expressed after CpG-oligodeoxyribonucleotide activation, and CD27 expressed on memory B cells, is a stronger differentiation promoter, indicating the role of pDCs in B-cell growth and differentiation [52,53].

In addition to abundant cytokine production, TLR-mediated activation leads to $\mathrm{pDC}$ maturation associated with upregulation of costimulatory molecules (CD40, CD80, CD86 and CD137L), increased expression of MHC class II and capability to stimulate T cells [54]. This process is specifically mediated by NF- $\kappa \beta$ signaling [28]. Activated pDCs can efficiently present antigens and prime and cross-prime T lymphocytes [55]. Different from cDCs, which have the ability to accumulate long-lived MHC class II-peptide complexes for a short period after activation, pDCs maintain the capacity to present antigens after activation, which is important when they become infected with viruses. The pDCs continuously display the repertoire of exogenous and endogenous antigens contained in the surrounding environment [55]. Recent studies demonstrated that pDCs could convert to cDCs after culture with certain stimuli (e.g, IL-3, CD40L, viruses or TLR ligands) [13], probably related to reduced transcription factor protein E2-2 expression [19]. This differentiation would automatically terminate high-level type I interferon secretion, shorten the lifespan of infected pDCs and facilitate T-cell priming to viral antigens [20].

The tolerogenic property of pDCs has been associated with the expression of the intracellular enzyme indoleamine 2,3-dioxygenase (IDO). IDO is rarely expressed by lymphoid cells under physiologic conditions. Its expression is tightly regulated and is responsive to inflammatory signals such as type I and II interferons [28]. Activated under certain conditions, pDCs may express IDO [55]. IDO catabolizes tryptophan, consumes reactive oxygen species [56] and generates metabolites known as kynurenines [57]. Its immunosuppressive effect may be linked to the reduction of local tryptophan concentration and kynurenine metabolites affecting activated T cells [58]. Furthermore, pDCs expressing 
IDO reduce their ability to stimulate clonal expansion of effector $\mathrm{T}$ cells, enhance their ability to suppress T-cell responses [28,59,60] and promote generation of Tregs [58].

In addition, human pDCs constitutively express high levels of ICOS-L [61], which promotes survival, expansion and IL-10 production of a subset of FoxP $3^{+}$Tregs expressing ICOS [62].

\section{Involvement of pDCs in human diseases}

Type I interferons are pleiotropic cytokines with antiviral activity that also enhance innate and adaptive immune responses [24]. However, chronic activation and secretion of type I interferons in the absence of infection can promote autoimmune diseases, for example, systemic lupus erythematosus (SLE) and psoriasis [63]. Furthermore, pDCs are able to migrate to affected peripheral tissues during inflammation, which lends further support to the view that pDCs are important players in innate and adaptive immunity in vivo [40]. For example, in psoriasis, early skin lesions are highly infiltrated with activated pDCs, corresponding with decreased numbers of circulating pDCs in the blood [64]. The aggregation of released cellular self-DNA and RNA into large complexes could efficiently activate pDCs $[29,65]$, although the origin of these immunostimulatory complexes remains to be elucidated. In SLE, the complexes of antinuclear antibodies and endogenous nucleic acid activate pDCs through TLR7 and TLR9, initiating type I interferon secretion $[66,67]$. SLE patients show increased serum levels of IFN- $\alpha / \beta$ that correlate with disease activity and severity [68].

In rheumatoid arthritis, $\mathrm{pDCs}$ are recruited to the synovium where they may contribute to the local inflammatory environment. However, different from SLE and psoriasis, pDC concentration and phenotype in peripheral blood of patients with rheumatoid arthritis are similar to healthy subjects $[69,70]$.

BST-2 or tetherin, a ligand of ILT-7, is expressed in many tumors, suggesting a likely mechanism whereby these tumors prevent $\mathrm{pDC}$ activation and escape tumor surveillance [20,71]. HIV and hepatitis B virus may inhibit pDC function by binding to their surface molecule BDCA-2 [72,73].

\section{pDCs in multiple sclerosis}

Multiple sclerosis (MS) is a chronic inflammatory disease of the CNS $[74,75]$. pDCs have been given particular emphasis due to their importance in stimulating or inhibiting effector $\mathrm{T}$ cells in MS [76]. Cytokines, such as type I interferon, IL-6 and TNF-a produced by pDCs, have been implicated in MS pathogenesis. Type I interferon promotes Th1 polarization [46] and IFN- $\gamma$ production [47]; IL-6 promotes myelin antigen-specific Th17 and Th1 responses in encephalomyelitis (EAE) [77]; and TNF-a directly induces oligodendrocyte apoptosis [78] and mediates human neuronal injury after activation with TLR9 agonists [79].

pDCs are present in the cerebrospinal fluid (CSF) [80], leptomeninges and demyelinating lesions of patients with MS [81] and their concentration is increased in the CSF of MS patients during an exacerbation [82]. Furthermore, the relative concentration (among all mononuclear cells) of pDCs is increased in the CSF in MS [80]. However, the concentration of pDCs in peripheral blood of patients with MS is comparable with healthy subjects [8385].

pDCs are difficult to study owing to their low concentration in peripheral blood. As a result, it is still not clear if pDCs play a predominantly pathogenic or protective role in MS (Figure 1). The ambivalent function of $\mathrm{pDCs}$ has also been observed in experimental autoimmune 
EAE, one of several animal models of human MS. It was suggested that pDCs promote priming of autoimmune Th17 in EAE, whereas depletion of pDCs prior to induction of the disease decreases its severity [86]. On the other hand, clinical signs of EAE were exacerbated considerably if pDCs were depleted during the peak period of the disease. pDC depletion enhanced CNS, but not peripheral, CD4-positive T-cell activation, as well as IL-17 and IFN- $\gamma$ production [76]. pDCs also function as important APCs that regulate the priming phase of EAE [87]. EAE was exacerbated in chimeric mice lacking MHC class II expressed on pDCs. Compared to the wild-type mice, the chimeric mice had increased myelin oligodendrocyte glycoprotein-specific IFN- $\gamma$ and IL-17 secretion by T cells, impaired Treg proliferation and decreased IL-10 production. No differences were observed in the production of type I interferons and other cytokines by pDCs, suggesting that the disease exacerbation was a result of the impaired antigen presentation by these cells [87]. The state of DC maturation affects antigen-presenting capabilities in humans as well [88].

The role of pDCs in immune regulation in MS has been addressed in several studies. The expression of the costimulatory molecule CD86 was decreased [85] or not changed [84] in pDCs isolated from patients with relapsing remitting MS. Expression of CD83, a costimulatory molecule and DC maturation marker, was decreased in pDCs in primary progressive MS patients [84]. CD137 is a member of the TNF receptor family, with stimulatory effect on T cells. The expression of CD137 ligand (4-1BBL) and CD86 was decreased in untreated relapsing-remitting multiple sclerosis patients compared with healthy controls [85]. In this study, treatment with glatiramer acetate restored the expression of CD86 [85]. Schwab et al. suggested that pDCs in human peripheral blood could be divided into two subsets. The first subset (BDCA-4 $4^{+}, \mathrm{CD} 123^{\text {low }}$ ) primes IL-17-secreting T cells. The second subset (BDCA- $4^{+}, \mathrm{CD} 123^{\text {high }}$ ) promotes generation of IL-10-secreting T cells [89]. Patients with MS had an increased ratio of CD123 low $\mathrm{pDCs}$ compared with healthy controls, which was corrected after immunomodulatory therapy with IFN- $\beta$. However, one may hypothesize that, in fact, these two phenotypic subsets represent different stages of pDC maturation.

In untreated MS patients, TLR9 agonist-activated pDCs produced increased levels of IFN-a compared with healthy subjects and IFN- $\beta$ - treated patients with comparable frequency of IFN-a-producing pDCs [90,91]. Furthermore, MS patients had increased production of CCL3, CCL4 and CCL5, chemokines that attract CCR5-positive Th1 cells, and upregulation of CCR7, the chemokine receptor that directs APCs to secondary lymph organs and possibly to sites of CNS inflammation. A recent gene expression microarray study revealed the complexity of disease-associated changes in pDCs. More than 1200 genes were differentially expressed in pDCs of untreated MS patients compared with healthy subjects. Expression of 60 genes was 'corrected' after treatment with IFN- $\beta$ [92].

\section{pDCs as potential therapeutic targets in MS}

The effect of immunomodulatory therapy on pDC phenotype and function has been reported [85-91,92]. Treatment with glatiramer acetate seems to restore the impaired maturation and altered regulatory function of pDCs in MS [85]. Activated pDCs had decreased ability to produce IFN- $\alpha$, IL-6, TNF- $\alpha$ and the chemokines CCL3, CCL4 and CCL5 in IFN- $\beta$-treated patients compared with untreated patients [91,92]. This effect may potentially lead to decreased migration of activated pDCs to the CNS and, afterwards, attraction of CCR $5^{+}$Th1 lymphocytes, which would diminish formation of new demyelinating lesions [38,92].

TLR9 is abundantly expressed in pDCs and appears to be important in the pathogenesis of EAE. Activation of APCs through TLR9 can overcome tolerance and precipitate EAE [9395], while $T L R 9$ knockout mice have decreased susceptibility to EAE [94]. By contrast, 
TLR3 stimulation suppresses EAE by activation of the MyD88-independent pathway [96]. TLR9 gene and protein expression in pDCs of patients with MS was comparable with healthy donors. However, it was identified that IFN- $\beta$ inhibited TLR9 processing necessary for TLR9-mediated activation of pDCs when compared with untreated MS patients [90]. In the present authors' recent study, pDC gene expression was analyzed by oligo microarrays before and after IFN- $\beta$ treatment in patients with relapsing form of MS. The expression of 283 genes was found to be affected by treatment [93].

Inhibitory oligodeoxyribonucleotides (INH-ODN), also called TLR9 antagonists, are able to block downstream signaling events in TLR9-expressing cells [97,98]. Some of these INHODNs can also target TLR7 signaling pathways. INH-ODNs are in the early stages of testing in vitro and in vivo. They are able to inhibit activation of human pDCs and B cells in vitro, block reactive arthritis and delay development of lupus nephritis in mice $[97,98]$. TLR antagonists could also offer a way to lower steroid dosage and thus reduce side effects in lupus patients [99]. INH-ODNs may be an optimal specific tool to prevent activation of TLR9-expressing pDCs by DNA viruses such as EBV, which have been implicated in MS pathogenesis $[100,101]$. The use of TLR9 antagonists may well have a major effect on MS.

Another potential therapeutic option would be to control $\mathrm{pDC}$ recruitment to the CNS through chemokine receptor antagonists, for example, antibodies against CCR7, CXCR4, CXCR5 or ChemR23. One may hypothesize that the reduction of activated pDCs in the CSF, leptomeninges and demyelinating lesions of patients with MS would attenuate the proinflammatory microenvironment. On the other hand, mature $\mathrm{pDCs}$, $\mathrm{pDCs}$ stimulated via surface molecules BDCA-2 and ILT-7 [36], and alternatively activated pDCs [102,103] promote tolerance. Increased expression of IDO in activated pDCs promotes generation of FoxP3 $^{+}$Tregs in vitro $[104,105]$.

\section{Conclusion}

Although many questions need to be addressed, modulation of $\mathrm{pDC}$ function has become a possible approach to restore impaired immune regulation in MS. Nevertheless, the exact role of these complicated cells in MS remains to be defined; the rationale for pDC transfusion as well as the need of pharmacological treatments affecting pDC function in MS have to be determined.

\section{Future perspective}

It is expected that the role of pDCs in MS will be more precisely defined in the near future. This will lead to clinical trials targeting specific molecules to modulate pDC functions.

\section{Acknowledgments}

The authors thank J Moore for her critical reading of the manuscript.

KE Balashov's research activity is supported in part by grant number K23NS052553 from the National Institute of Neurological Disorders and Stroke. KE Balashov has served as a consultant for Biogen Idec, Bayer Healthcare, Genzyme and TEVA Neuroscience in the past. Research grant support to KE Balashov from Bayer Healthcare, Biogen Idec, TEVA Neuroscience have been received or pending.

\section{References}

Papers of special note have been highlighted as:

- of interest 
1. Lennert K, Remmele W. Karyometric research on lymph node cells in man. I Germinoblasts, lymphoblasts \& lymphocytes. Acta Haematol. 1958; 19(2):99-113. [PubMed: 13520253]

2. Facchetti F, de Wolf-Peeters C, Mason D, Pulford K, van den Oord J, Desmet V. Plasmacytoid T cells. Immunohistochemical evidence for their monocyte/macrophage origin. Am. J. Pathol. 1988; 133(1):15-21. [PubMed: 3052093]

3. Grouard G, Rissoan M, Filgueira L, Durand I, Banchereau J, Liu Y. The enigmatic plasmacytoid T cells develop into dendritic cells with interleukin (IL)-3 and CD40-ligand. J. Exp. Med. 1997; 185(6):1101-1111. [PubMed: 9091583]

4. Siegal FP, Kadowaki N, Shodell M, et al. The nature of the principal type 1 interferon-producing cells in human blood. Science. 1999; 284(5421):1835-1837. [PubMed: 10364556]

5. Cella M, Jarrossay D, Facchetti F, et al. Plasmacytoid monocytes migrate to inflamed lymph nodes and produce large amounts of type I interferon. Nat. Med. 1999; 5(8):919-923. [PubMed: 10426316]

6. Dzionek A, Fuchs A, Schmidt P, et al. BDCA-2, BDCA-3, and BDCA-4: three markers for distinct subsets of dendritic cells in human peripheral blood. J. Immunol. 2000; 165(11):6037-6046. [PubMed: 11086035] - Seminal paper on human plasmacytoid dendritic cell (pDC)-specific surface markers.

7. Dzionek A, Sohma Y, Nagafune J, et al. BDCA-2, a novel plasmacytoid dendritic cell-specific type II C-type lectin, mediates antigen capture and is a potent inhibitor of interferon alpha/beta induction. J. Exp. Med. 2001; 194(12):1823-1834. [PubMed: 11748283]

8. Asselin-Paturel C, Boonstra A, Dalod M, et al. Mouse type I IFN-producing cells are immature APCs with plasmacytoid morphology. Nat. Immunol. 2001; 2(12):1144-1150. [PubMed: 11713464]

9. Nakano H, Yanagita M, Gunn MD. CD11c(+)B220(+)Gr-1(+) cells in mouse lymph nodes and spleen display characteristics of plasmacytoid dendritic cells. J. Exp. Med. 2001; 194(8):11711178. [PubMed: 11602645]

10. Bjorck P. Isolation and characterization of plasmacytoid dendritic cells from Flt3 ligand and granulocyte-macrophage colony-stimulating factor-treated mice. Blood. 2001; 98(13):3520-3526. [PubMed: 11739152]

11. Blom B, Ho S, Antonenko S, Liu YJ. Generation of interferon alpha-producing predendritic cell (pre-DC)2 from human CD34(+) hematopoietic stem cells. J. Exp. Med. 2000; 192(12):17851796. [PubMed: 11120775]

12. Gilliet M, Boonstra A, Paturel C, et al. The development of murine plasmacytoid dendritic cell precursors is differentially regulated by FLT3-ligand and granulocyte/macrophage colonystimulating factor. J. Exp. Med. 2002; 195(7):953-958. [PubMed: 11927638]

13. Soumelis V, Liu YJ. From plasmacytoid to dendritic cell: morphological and functional switches during plasmacytoid pre-dendritic cell differentiation. Eur. J. Immunol. 2006; 36(9):2286-2292. [PubMed: 16892183]

14. Olweus J, Bitmansour A, Warnke R, et al. Dendritic cell ontogeny: a human dendritic cell lineage of myeloid origin. Proc. Natl Acad. Sci. USA. 1997; 94(23):12551-12556. [PubMed: 9356487]

15. Segura E, Valladeau-Guilemond J, Donnadieu MH, et al. Characterization of resident and migratory dendritic cells in human lymph nodes. J. Exp. Med. 2012; 209:653-660. [PubMed: 22430490]

16. Naik SH, Sathe P, Park HY, et al. Development of plasmacytoid and conventional dendritic cell subtypes from single precursor cells derived in vitro and in vivo. Nat. Immunol. 2007; 8(11): 1217-1226. [PubMed: 17922015]

17. Onai N, Obata-Onai A, Schmid MA, Ohteki T, Jarrossay D, Manz M. Identification of clonogenic common Flt $3^{+} \mathrm{M}-\mathrm{CSFR}^{+}$plasmacytoid and conventional dendritic cell progenitors in mouse bone marrow. Nat. Immunol. 2007; 8(11):1207-1216. [PubMed: 17922016]

18. Schmid M, Kingston D, Boddupalli S, Manz M. Instructive cytokine signals in dendritic cell lineage commitment. Immunol. Rev. 2010; 234(1):32-44. [PubMed: 20193010]

19. Cisse B, Caton M, Lehner M, et al. Transcription factor E2-2 is an essential and specific regulator of plasmacytoid dendritic cell development. Cell. 2008; 135(1):37-48. [PubMed: 18854153] 
20. Reizis B, Bunin A, Ghosh HS, Lewis KL, Sisirak V. Plasmacytoid dendritic cells: recent progress and open questions. Annu. Rev. Immunol. 2011; 29:163-183. [PubMed: 21219184]

21. Shigematsu H, Reizis B, Iwasaki H, et al. Plasmacytoid dendritic cells activate lymphoid-specific genetic programs irrespective of their cellular origin. Immunity. 2004; 21(1):43-53. [PubMed: 15345219]

22. Rissoan MC, Duhen T, Bridon JM, et al. Subtractive hybridization reveals the expression of immunoglobulin-like transcript 7, Eph-B1, granzyme B, and 3 novel transcripts in human plasmacytoid dendritic cells. Blood. 2002; 100(9):3295-3303. [PubMed: 12384430]

23. Cao W, Rosen DB, Ito T, et al. Plasmacytoid dendritic cell-specific receptor ILT-7-Fc epsilonRI gamma inhibits Toll-like receptor-induced interferon production. J. Exp. Med. 2006; 203(6):13991405. [PubMed: 16735691]

24. Swiecki M, Colonna M. Unraveling the functions of plasmacytoid dendritic cells during viral infections, autoimmunity, and tolerance. Immunol. Rev. 2010; 234(1):142-162. [PubMed: 20193017]

25. Liu YJ. IPC: professional type 1 interferon-producing cells and plasmacytoid dendritic cell precursors. Annu. Rev. Immunol. 2005; 23:275-306. [PubMed: 15771572] • Good comprehensive review on human pDCs.

26. Honda K, Yanai H, Negishi H, et al. IRF-7 is the master regulator of type-I interferon-dependent immune responses. Nature. 2005; 434(7034):772-777. [PubMed: 15800576]

27. Kawai T, Sato S, Ishii KJ, et al. Interferon-alpha induction through Toll-like receptors involves a direct interaction of IRF7 with MyD88 and TRAF6. Nat. Immunol. 2004; 5(10):1061-1068. [PubMed: 15361868]

28. O'Keeffe M, Grumont RJ, Hochrein H, et al. Distinct roles for the NF-kappaB1 and c-Rel transcription factors in the differentiation and survival of plasmacytoid and conventional dendritic cells activated by TLR-9 signals. Blood. 2005; 106(10):3457-3464. [PubMed: 16037393]

29. Lande R, Gregorio J, Facchinetti V, et al. Plasmacytoid dendritic cells sense self-DNA coupled with antimicrobial peptide. Nature. 2007; 449(7162):564-569. [PubMed: 17873860]

30. Lund JM, Alexopoulou L, Sato A, et al. Recognition of single-stranded RNA viruses by Toll-like receptor 7. Proc. Natl Acad. Sci. USA. 2004; 101(15):5598-5603. [PubMed: 15034168]

31. Heil F, Hemmi H, Hochrein H, et al. Species-specific recognition of single-stranded RNA via Tolllike receptor 7 and 8. Science. 2004; 303(5663):1526-1529. [PubMed: 14976262]

32. Haas T, Metzger J, Schmitz F, et al. The DNA sugar backbone $2^{\prime}$ deoxyribose determines Tolllike receptor 9 activation. Immunity. 2008; 28(3):315-323. [PubMed: 18342006]

33. Lund J, Sato A, Akira S, Medzhitov R, Iwasaki A. Toll-like receptor 9-mediated recognition of Herpes simplex virus-2 by plasmacytoid dendritic cells. J. Exp. Med. 2003; 198(3):513-520. [PubMed: 12900525]

34. Barchet W, Cella M, Odermatt B, Asselin-Paturel C, Colonna M, Kalinke U. Virus-induced interferon alpha production by a dendritic cell subset in the absence of feedback signaling in vivo. J. Exp. Med. 2002; 195(4):507-516. [PubMed: 11854363]

35. Kerkmann M, Rothenfusser S, Hornung V, et al. Activation with CpG-A and CpG-B oligonucleotides reveals two distinct regulatory pathways of type I IFN synthesis in human plasmacytoid dendritic cells. J. Immunol. 2003; 170(9):4465-4474. [PubMed: 12707322]

36. Gilliet M, Cao W, Liu YJ. Plasmacytoid dendritic cells: sensing nucleic acids in viral infection and autoimmune diseases. Nat. Rev. Immunol. 2008; 8(8):594-606. [PubMed: 18641647]

37. Fuchs A, Cella M, Kondo T, Colonna M. Paradoxic inhibition of human natural interferonproducing cells by the activating receptor NKp44. Blood. 2005; 106(6):2076-2082. [PubMed: 15941912]

38. Penna G, Vulcano M, Roncari A, Facchetti F, Sozzani S, Adorini L. Cutting edge: differential chemokine production by myeloid and plasmacytoid dendritic cells. J. Immunol. 2002; 169(12): 6673-6676. [PubMed: 12471096]

39. Sozzani S, Allavena P, D'Amico G, et al. Differential regulation of chemokine receptors during dendritic cell maturation: a model for their trafficking properties. J. Immunol. 1998; 161:10831086. [PubMed: 9686565] 
40. Jahnsen FL, Farkas L, Lund-Johansen F, Brandtzaeg P. Involvement of plasmacytoid dendritic cells in human diseases. Hum. Immunol. 2002; 63(12):1201-1205. [PubMed: 12480264]

41. Zabel BA, Silverio AM, Butcher EC. Chemokine-like receptor 1 expression and chemerin-directed chemotaxis distinguish plasmacytoid from myeloid dendritic cells in human blood. J. Immunol. 2005; 174(1):244-251. [PubMed: 15611246]

42. Schnurr M, Toy T, Shin A, et al. Role of adenosine receptors in regulating chemotaxis and cytokine production of plasmacytoid dendritic cells. Blood. 2004; 103(4):1391-1397. [PubMed: 14551144]

43. Gutzmer R, Kother B, Zwirner J, et al. Human plasmacytoid dendritic cells express receptors for anaphylatoxins C3a and C5a and are chemoattracted to C3a and C5a. J. Invest. Dermatol. 2006; 126(11):2422-2429. [PubMed: 16778800]

44. Marrack P, Kappler J, Mitchell T. Type I interferons keep activated T cells alive. J. Exp. Med. 1999; 189(3):521-530. [PubMed: 9927514]

45. Kolumam GA, Thomas S, Thompson LJ, Sprent J, Murali-Krishna K. Type I interferons act directly on CD8 T cells to allow clonal expansion and memory formation in response to viral infection. J. Exp. Med. 2005; 202(5):637-650. [PubMed: 16129706]

46. Trinchieri G. Interleukin-12 and the regulation of innate resistance and adaptive immunity. Nat. Rev. Immunol. 2003; 3(2):133-146. [PubMed: 12563297]

47. Mescher MF, Curtsinger JM, Agarwal P, et al. Signals required for programming effector and memory development by CD8 ${ }^{+}$T cells. Immunol. Rev. 2006; 211:81-92. [PubMed: 16824119]

48. Biron CA. Interferons alpha and beta as immune regulators - a new look. Immunity. 2001; 14(6): 661-664. [PubMed: 11420036]

49. Rissoan MC, Soumelis V, Kadowaki N, et al. Reciprocal control of T helper cell and dendritic cell differentiation. Science. 1999; 283(5405):1183-1186. [PubMed: 10024247]

50. Jego G, Palucka AK, Blanck JP, Chalouni C, Pascual V, Banchereau J. Plasmacytoid dendritic cells induce plasma cell differentiation through type I interferon and interleukin 6. Immunity. 2003; 19(2):225-234. [PubMed: 12932356]

51. Poeck H, Wagner M, Battiany J, et al. Plasmacytoid dendritic cells, antigen, and CpG-C license human B cells for plasma cell differentiation and immunoglobulin production in the absence of Tcell help. Blood. 2004; 103(8):3058-3064. [PubMed: 15070685]

52. Shaw J, Wang YH, Ito T, Arima K, Liu YJ. Plasmacytoid dendritic cells regulate B-cell growth and differentiation via CD70. Blood. 2010; 115(15):3051-3057. [PubMed: 20139096]

53. Douagi I, Gujer C, Sundling C, et al. Human B cell responses to TLR ligands are differentially modulated by myeloid and plasmacytoid dendritic cells. J. Immunol. 2009; 182(4):1991-2001. [PubMed: 19201852]

54. Villadangos JA, Young L. Antigen-presentation properties of plasmacytoid dendritic cells. Immunity. 2008; 29(3):352-361. [PubMed: 18799143]

55. Munn DH, Sharma MD, Mellor AL. Ligation of B7-1/B7-2 by human CD4 ${ }^{+} \mathrm{T}$ cells triggers indoleamine 2,3-dioxygenase activity in dendritic cells. J. Immunol. 2004; 172(7):4100-4110. [PubMed: 15034022]

56. Thomas SR, Stocker R. Antioxidant activities and redox regulation of interferon-gamma-induced tryptophan metabolism in human monocytes and macrophages. Adv. Exp. Med. Biol. 1999; 467:541-552. [PubMed: 10721098]

57. Taylor MW, Feng GS. Relationship between interferon-gamma, indoleamine 2,3-dioxygenase, and tryptophan catabolism. FASEB J. 1991; 5(11):2516-2522. [PubMed: 1907934]

58. Kwidzinski E, Bechmann I. IDO expression in the brain: a double-edged sword. J. Mol. Med. (Berl.). 2007; 85(12):1351-1359. [PubMed: 17594069]

59. Manlapat AK, Kahler DJ, Chandler PR, Munn DH, Mellor AL. Cell-autonomous control of interferon type I expression by indoleamine 2,3-dioxygenase in regulatory $\mathrm{CD} 19^{+}$dendritic cells. Eur. J. Immunol. 2007; 37(4):1064-1071. [PubMed: 17343295]

60. Hill M, Tanguy-Royer S, Royer P, et al. IDO expands human $\mathrm{CD} 4^{+} \mathrm{CD} 25^{\text {high }}$ regulatory $\mathrm{T}$ cells by promoting maturation of LPS-treated dendritic cells. Eur. J. Immunol. 2007; 37(11):3054-3062. [PubMed: 17948274] 
61. Ito T, Hanabuchi S, Wang YH, et al. Two functional subsets of FOXP3 ${ }^{+}$regulatory T cells in human thymus and periphery. Immunity. 2008; 28(6):870-880. [PubMed: 18513999]

62. Ito T, Yang M, Wang YH, et al. Plasmacytoid dendritic cells prime IL-10-producing T regulatory cells by inducible costimulator ligand. J. Exp. Med. 2007; 204(1):105-115. [PubMed: 17200410]

63. Ronnblom L, Alm GV. A pivotal role for the natural interferon alpha-producing cells (plasmacytoid dendritic cells) in the pathogenesis of lupus. J. Exp. Med. 2001; 194(12):F59-F63. [PubMed: 11748288]

64. Nestle FO, Conrad C, Tun-Kyi A, et al. Plasmacytoid predendritic cells initiate psoriasis through interferon-alpha production. J. Exp. Med. 2005; 202(1):135-143. [PubMed: 15998792]

65. Ganguly D, Chamilos G, Lande R, et al. Self-RNA-antimicrobial peptide complexes activate human dendritic cells through TLR7 and TLR8. J. Exp. Med. 2009; 206(9):1983-1994. [PubMed: 19703986]

66. Bave U, Magnusson M, Eloranta ML, Perers A, Alm GV, Ronnblom L. Fc gamma RIIa is expressed on natural IFN-alpha-producing cells (plasmacytoid dendritic cells) and is required for the IFN-alpha production induced by apoptotic cells combined with lupus IgG. J. Immunol. 2003; 171(6):3296-3302. [PubMed: 12960360]

67. Barrat FJ, Meeker T, Gregorio J, et al. Nucleic acids of mammalian origin can act as endogenous ligands for Toll-like receptors and may promote systemic lupus erythematosus. J. Exp. Med. 2005; 202(8):1131-1139. [PubMed: 16230478]

68. Baechler EC, Batliwalla FM, Karypis G, et al. Interferon-inducible gene expression signature in peripheral blood cells of patients with severe lupus. Proc. Natl Acad. Sci. USA. 2003; 100(5): 2610-2615. [PubMed: 12604793]

69. Cavanagh LL, Boyce A, Smith L, et al. Rheumatoid arthritis synovium contains plasmacytoid dendritic cells. Arthritis Res. Ther. 2005; 7(2):R230-R240. [PubMed: 15743469]

70. Takakubo Y, Takagi M, Maeda K, et al. Distribution of myeloid dendritic cells and plasmacytoid dendritic cells in the synovial tissues of rheumatoid arthritis. J. Rheumatol. 2008; 35(10):19191931. [PubMed: 18785315]

71. Cao W, Bover L, Cho M, et al. Regulation of TLR7/9 responses in plasmacytoid dendritic cells by BST2 and ILT- receptor interaction. J. Exp. Med. 2009; 206(7):1603-1614. [PubMed: 19564354]

72. Martinelli E, Cicala C, Van Ryk D, et al. HIV-1 gp120 inhibits TLR9-mediated activation and IFN-\{alpha\} secretion in plasmacytoid dendritic cells. Proc. Natl Acad. Sci. USA. 2007; 104(9): 3396-3401. [PubMed: 17360657]

73. Xu Y, Hu Y, Shi B, et al. HBsAg inhibits TLR9-mediated activation and IFN-alpha production in plasmacytoid dendritic cells. Mol. Immunol. 2009; 46(13):2640-2646. [PubMed: 19501403]

74. Noseworthy JH, Lucchinetti C, Rodriguez M, Weinshenker BG. Multiple sclerosis. N. Engl. J. Med. 2000; 343(13):938-952. [PubMed: 11006371]

75. Sospedra M, Martin R. Immunology of multiple sclerosis. Annu. Rev. Immunol. 2005; 23:683747. [PubMed: 15771584]

76. Bailey-Bucktrout SL, Caulkins SC, Goings G, Fischer JA, Dzionek A, Miller SD. Cutting edge: central nervous system plasmacytoid dendritic cells regulate the severity of relapsing experimental autoimmune encephalomyelitis. J. Immunol. 2008; 180(10):6457-6461. [PubMed: 18453561]

77. Serada S, Fujimoto M, Mihara M, et al. IL-6 blockade inhibits the induction of myelin antigenspecific Th17 cells and Th1 cells in experimental autoimmune encephalomyelitis. Proc. Natl Acad. Sci. USA. 2008; 105:9041-9046. [PubMed: 18577591]

78. Akassoglou K, Bauer J, Kassiotis G, et al. Oligodendrocyte apoptosis and primary demyelination induced by local TNF/p55TNF receptor signaling in the central nervous system of transgenic mice: models for multiple sclerosis with primary oligodendrogliopathy. Am. J. Pathol. 1998; 153:801-813. [PubMed: 9736029]

79. Iliev AI, Stringaris AK, Nau R, et al. Neuronal injury mediated via stimulation of microglial Tolllike receptor-9 (TLR9). FASEB J. 2004; 18:412-414. [PubMed: 14688201]

80. Pashenkov M, Huang YM, Kostulas V, Haglund M, Soderstrom M, Link H. Two subsets of dendritic cells are present in human cerebrospinal fluid. Brain. 2001; 124(Pt 3):480-492. [PubMed: 11222448] - First paper that described dendritic cell subsets in patients with multiple sclerosis. 
81. Lande R, Gafa V, Serafini B, et al. Plasmacytoid dendritic cells in multiple sclerosis: intracerebral recruitment and impaired maturation in response to interferon-beta. J. Neuropathol. Exp. Neurol. 2008; 67(5):388-401. [PubMed: 18431257]

82. Longhini AL, von Glehn F, Brandao CO, et al. Plasmacytoid dendritic cells are increased in cerebrospinal fluid of untreated patients during multiple sclerosis relapse. J. Neuroinflammation. 2011; 8(1):2. [PubMed: 21214939] - Reports that the concentration of pDCs in the cerebrospinal fluid is increased during multiple sclerosis relapse.

83. Pashenkov M, Teleshova N, Kouwenhoven M, et al. Elevated expression of CCR5 by myeloid $\left(\mathrm{CD} 11 \mathrm{c}^{+}\right)$blood dendritic cells in multiple sclerosis and acute optic neuritis. Clin. Exp. Immunol. 2002; 127(3):519-526. [PubMed: 11966770]

84. Lopez C, Comabella M, Al-Zayat H, Tintore M, Montalban X. Altered maturation of circulating dendritic cells in primary progressive MS patients. J. Neuroimmunol. 2006; 175(1-2):183-191. [PubMed: 16698091]

85. Stasiolek M, Bayas A, Kruse N, et al. Impaired maturation and altered regulatory function of plasmacytoid dendritic cells in multiple sclerosis. Brain. 2006; 129:1293-1305. [PubMed: 16513684]

86. Isaksson M, Ardesjo B, Ronnblom L, et al. Plasmacytoid DC promote priming of autoimmune Th17 cells and EAE. Eur. J. Immunol. 2009; 39(10):2925-2935. [PubMed: 19637225]

87. Irla M, Kupfer N, Suter T, et al. MHC class II-restricted antigen presentation by plasmacytoid dendritic cells inhibits T cell-mediated autoimmunity. J. Exp. Med. 2010; 207(9):1891-1905. [PubMed: 20696698]

88. Dhodapkar MV, Steinman RM, Krasovsky J, et al. Antigen-specific inhibition of effector T cell function in humans after injection of immature dendritic cells. J. Exp. Med. 2001; 193:233-238. [PubMed: 11208863]

89. Schwab N, Zozulya AL, Kieseier BC, et al. An imbalance of two functionally and phenotypically different subsets of plasmacytoid dendritic cells characterizes the dysfunctional immune regulation in multiple sclerosis. J. Immunol. 2010; 184:5368-5374. [PubMed: 20357264]

90. Balashov KE, Aung LL, Vaknin-Dembinsky A, et al. Interferon-beta inhibits Toll-like receptor 9 processing in multiple sclerosis. Ann. Neurol. 2010; 68(6):899-906. [PubMed: 21061396] • Reports that TLR-9 processing in pDCs is targeted by IFN- $\beta$ treatment in patients with multiple sclerosis.

91. Aung LL, Fitzgerald-Bocarsly P, Dhib-Jalbut S, Balashov K. Plasmacytoid dendritic cells in multiple sclerosis: chemokine and chemokine receptor modulation by interferon-beta. J. Neuroimmunol. 2010; 226:158-164. [PubMed: 20621365]

92. Aung LL, Brooks A, Greenberg SA, Rosenberg ML, Dhib-Jalbut S, Balashov KE. Multiple sclerosis-linked and interferon-beta-regulated gene expression in plasmacytoid dendritic cells. J. Neuroimmunol. 2012; 250(1-2):99-105. [PubMed: 22688425]

93. Segal BM, Chang JT, Shevach EM. CpG oligonucleotides are potent adjuvants for the activation of autoreactive encephalitogenic T cells in vivo. J. Immunol. 2000; 164(11):5683-5688. [PubMed: 10820244]

94. Ichikawa HT, Williams LP, Segal BM. Activation of APCs through CD40 or Toll-like receptor 9 overcomes tolerance and precipitates autoimmune disease. J. Immunol. 2002; 169(5):2781-2787. [PubMed: 12193753]

95. Waldner H, Collins M, Kuchroo VK. Activation of antigen-presenting cells by microbial products breaks self-tolerance and induces autoimmune disease. J. Clin. Invest. 2004; 113(7):990-997. [PubMed: 15057305]

96. Touil T, Fitzgerald D, Zhang GX, et al. Cutting edge: TLR3 stimulation suppresses experimental autoimmune encephalomyelitis by inducing endogenous IFN-beta. J. Immunol. 2006; 177(11): 7505-7509. [PubMed: 17114417]

97. Lenert P, Goeken AJ, Ashman RF. Extended sequence preferences for oligodeoxyribonucleotide activity. Immunology. 2006; 117(4):474-481. [PubMed: 16556261]

98. Lenert PS. Targeting Toll-like receptor signaling in plasmacytoid dendritic cells and autoreactive B cells as a therapy for lupus. Arthritis Res. Ther. 2006; 8(1):203. [PubMed: 16542467] 
99. Guiducci C, Gong M, Xu Z, et al. TLR recognition of self-nucleic acids hampers glucocorticoid activity in lupus. Nature. 2010; 465(7300):937-941. [PubMed: 20559388]

100. Levin LI, Munger KL, O'Reilly EJ, et al. Primary infection with the Epstein-Barr virus and risk of multiple sclerosis. Ann. Neurol. 2010; 67:824-830. [PubMed: 20517945]

101. Ascherio A, Munger KL. Environmental risk factors for multiple sclerosis. Part I: the role of infection. Ann. Neurol. 2007; 61:288-299. [PubMed: 17444504]

102. Hanabuchi S, Ito T, Park WR, et al. Thymic stromal lymphopoietin-activated plasmacytoid dendritic cells induce the generation of $\mathrm{FOXP}^{+}$regulatory $\mathrm{T}$ cells in human thymus. J. Immunol. 2010; 184:2999-3007. [PubMed: 20173030]

103. Martin-Gayo E, Sierra-Filardi E, Corbi AL, et al. Plasmacytoid dendritic cells resident in human thymus drive natural Treg cell development. Blood. 2010; 115:5366-5375. [PubMed: 20357241]

104. Chen W, Liang X, Peterson AJ, et al. The indoleamine 2,3-dioxygenase pathway is essential for human plasmacytoid dendritic cell-induced adaptive T regulatory cell generation. J. Immunol. 2008; 181:5396-5404. [PubMed: 18832696]

105. Pallotta MT, Orabona C, Volpi C, et al. Indoleamine 2,3-dioxygenase is a signaling protein in long-term tolerance by dendritic cells. Nat. Immunol. 2011; 12:870-878. [PubMed: 21804557] 


\section{Executive summary}

\section{Characterization of plasmacytoid dendritic cells}

- Plasmacytoid dendritic cells (pDCs) are specialized APCs.

- Compared with other APCs, pDCs express a high level of TLR9 and produce large amounts of type I interferon and other proinflammatory cytokines and chemokines upon stimulation with viral pathogens.

- pDCs regulate both innate and adaptive immune responses.

\section{Involvement of pDCs in human diseases}

- $\quad$ pDCs have been implicated in the pathogenesis of many human diseases.

\section{pDCs in multiple sclerosis}

- $\quad \mathrm{pDCs}$ are present in the cerebrospinal fluid, leptomeninges and demyelinating lesions of patients with multiple sclerosis (MS) and their concentration is increased in the cerebrospinal fluid of MS patients during an exacerbation.

- The exact role of pDCs in MS is not clear. They have both pathogenic and protective functions in MS. More than 1200 genes are differentially expressed in pDCs of MS patients compared with healthy subjects.

\section{pDCs as potential therapeutic targets in MS}

- There are multiple pharmacological options to target pDCs and modulate their functions.

- The exact role of these complicated cells in MS has to be determined before clinical trials specifically targeting pDCs are initiated. 


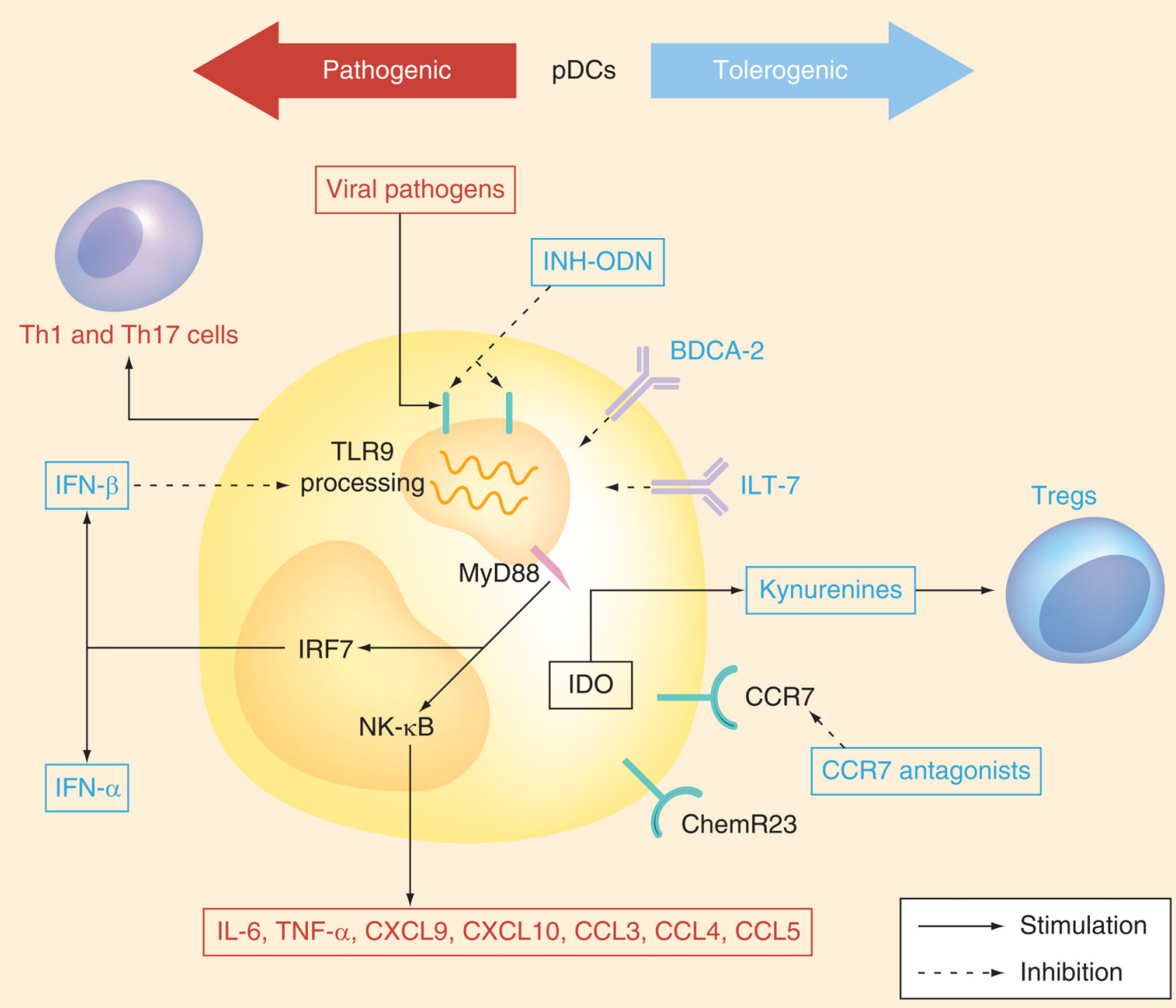

Figure 1. Plasmacytoid dendritic cells in multiple sclerosis

Plasmacytoid dendritic cells can be activated with viral and bacterial DNA via TLR9.

Activated pDCs promote generation of both Th1/Th17 cells $[46,76,87,92]$ and Tregs

$[104,105]$. IFN- $\beta$ treatment decreases the ability of pDCs to produce IFN- $a$, IL-6, TNF- $a$ and chemokines CCL3, CCL4 and CCL5 [90], as well as inhibiting TLR9 processing necessary for TLR9-mediated activation of pDCs [87]. INH-ODNs, also called TLR9 antagonists, block downstream signaling events in TLR9-mediated activation [97,98]. BDCA-2 and ILT-7 inhibit human pDC functions, attenuating TLR-induced production of type I interferon and other cytokines [36]. Induction of IDO in human pDCs is implicated in Treg generation [104,105]. Blocking chemokine receptors (e.g., CCR7 or ChemR23) would control activated pDC recruitment to the CNS. IDO: Indoleamine 2,3-dioxygenase; INHODN: Inhibitory oligodeoxyribonucleotide; pDC: Plasmacytoid dendritic cell. 